\title{
THE ALLEVIATORY EFFECTS OF THE DIODE LASER IN TREATING 4300 CASES OF PAIN
}

\author{
* 白戸千之, 小野慶一 \\ **大城俊夫 \\ * Chiyuki Shiroto, Keiichi Ono and \\ ** Toshio Ohshiro \\ * 弘前大学第 II 外科 \\ ** 日本医用レーザー研究所 \\ * IInd Dept. of Surg. School of Med. Hirosaki University. \\ ** Japan Medical Laser Laboratory.
}

We have been continuing pain alleviating therapy using a low-power diode laser 'panalas 4000', It operates at a wavelength of 830 nanometers and has a power output of $60 \mathrm{~mW}$. Here, we would like to report the experience of 4300 cases more.

The patients in this study were treated over a 34 month period between April 1984 and February 1987, and the total number of patients came to 2.840, with a total of 4,374 complaints. Treatment was so effective that almost patients felt immediatly relief from pain. Result were about $840 \%$ effective cure rate.

我及は第 $5 ， 6 ， 7$ 回の本大会に於て，「半導全実施回数は 48,988 回， 1 症例平均実施回数は 体レーザーの除痛に対する私見」と題して報告し 11.2回であり，当然実施回数の堌加から 1 症例平 て来たが，今回はその後の経験を加えた約 34 ケ 均回数も増加しているが、てれまでも述べている 間の治験を新たに検討したのでし〉に報告したい。様に、術者及び患者相方の慣れからロスタイムの

使用したのは従来通り，日本医用レーザー研究減少と，効果発現までの時間短縮により，1回の 所亡松下電気産業株式会社とによって開発された，実施秒数は逆に減少している。

疼痛綏解装置パナラス4000で, $60 \mathrm{~mW}, 830 \mathrm{~nm} の$ 疼痛の種類とその症例数については表に示した 半導体レーザーを内蔵したものである。 如くで11種類の疼痛に分類し，それにしびれと耳

実施期間は1984年末〜1987年 2 月末までの約 34 ケ月間で, 患者総数2,840名, 男性1,148名, 女性 1,692名であり，疾患別症例数は4,374例, 男性 1,597 例，女性2,777例となった。乙れは同一患者が多く の部位の疼挥を訴えた場合, その夫及在 1 症例之 して分離して統計をとったためで，1患者が約 1.5 症例となっている。 鴽りを加えて計13種類について検討してみた。ま た今回の統計ではてれまで報告して来た将患分類 に再検討を加え判然としない矮患名の見直しと， これまで左右別及に分けていたもの在一つにする などしたため一部の症例に数の增減をみている。 今回は娭患别に平均年令, 平均実施秒数, 平均 実施回数を比较してみたが, 全体として大きな変 


\section{治験 内容}

実施期間

患 者 総 数 疾患別症例数 平均年龄 全实施回数 1 症例平均回数 最少实施回数

最大实施回数

1 回平均実施秒数
昭和 59 年 4 月末一昭和 62 年2月末 (34ヶ月間)

2,840 名 (男 1,148人、女 1,692 人)

4,374 例 (男 1,597例、女 2,777 例)

53.6 歲 (男 50.9 藏、女 54.5 歳)

48,988回

11.2 回

1回

289回

316 秒(5分 16 秒)

化がみられないもの〉, 難治性のリウマチで最も 治療回数も多く，治療秒数も長く，それでいて治 療効果も低いととが強く印象に残った。しびれに ついても同じ䪸向がみられた。

治療効果について我々はこれまでの報告では, 夫々の症例の最終治療後の効果をもとに患者の自 覚症状によって有効率在算出して来た。今回も患 者の自覚症状により効果分類をしたが，乙れまで の様に最終治療時の効果によらず，夫及の患者の 全治療後の効果を合計し平均をとってその患者の 治療効果を出してみた。その結果は著効 $34.6 \%$, 有効 $49.4 \%$, 微効 $12.7 \%$, 不変 $3.4 \%$. 增悪 $0.1 \%$

疾患別治療内訳(全症例)

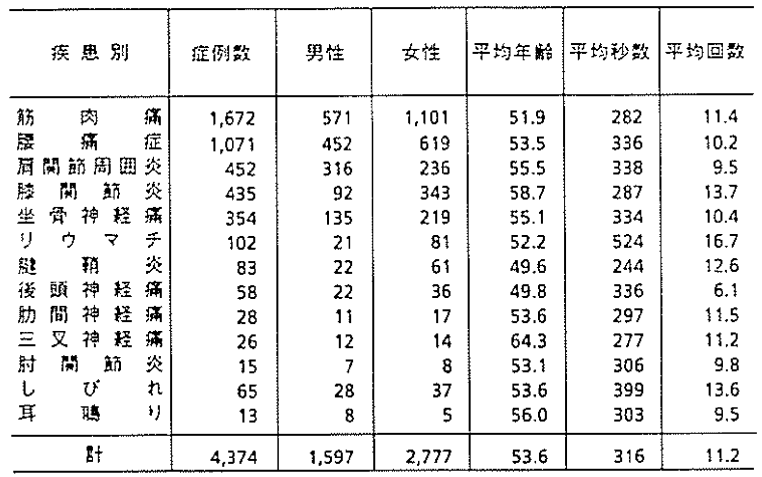

治療効果(筋肉痛)

\begin{tabular}{|c|c|c|c|c|c|c|c|c|c|}
\hline \multirow[b]{2}{*}{ 踢 } & \multirow[b]{2}{*}{ 患 } & \multirow[b]{2}{*}{ 脶 } & \multirow[b]{2}{*}{ 鿊例数 } & \multicolumn{5}{|c|}{ 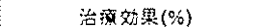 } & \multirow{2}{*}{$\begin{array}{c}\text { 夜对) } \\
(++i)+(+) \\
\%\end{array}$} \\
\hline & & & & 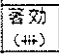 & $\begin{array}{l}\text { 有 } \\
(++)\end{array}$ & 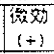 & $\begin{array}{l}7 \text { 宊 } \\
( \pm)\end{array}$ & 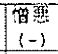 & \\
\hline & 泟 & & 715 & 36.0 & 52.4 & 9.3 & 2.3 & 0 & 88.4 \\
\hline$F$ & & 肢 & 454 & 36.4 & 46.2 & 13.9 & 3.4 & 0 & 82.6 \\
\hline 上 & & 肢 & 285 & 30.5 & 50.7 & 15.1 & 3.7 & 0 & 81.2 \\
\hline 訪 & 耑 & ב马ㄱ & 182 & 36.9 & 50.6 & 10.0 & 2.5 & 0 & 87.5 \\
\hline$\triangleq$ & & 身 & 36 & 46.0 & 46.0 & 8.0 & 0 & 0 & 92.0 \\
\hline & $\bar{s} t$ & & 1,672 & 35.5 & 49.5 & 12.1 & 2.9 & 0 & 85.0 \\
\hline
\end{tabular}

治療効果(全症例) その1

\begin{tabular}{|c|c|c|c|c|c|c|c|}
\hline & & & & 效果 & $\%)$ & & 有好车 \\
\hline 思別 & 症例数 & 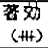 & $\begin{array}{l}\text { 有效 } \\
(+++)\end{array}$ & $\begin{array}{r}\text { 復效 } \\
(+)\end{array}$ & $\begin{array}{l}\text { 不堆 } \\
( \pm)\end{array}$ & 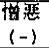 & $\begin{array}{c}(\text { H) })+(+) \\
\%\end{array}$ \\
\hline 肉 & 1,672 & 35.5 & 49.5 & 12.1 & 2.9 & 0 & 85.0 \\
\hline 霉 & 1,071 & 36.5 & 48.5 & 12.3 & 2.7 & 0 & 85.0 \\
\hline 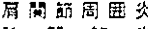 & 452 & 36.0 & 49.6 & 12.0 & 2.2 & 0 & 85.6 \\
\hline 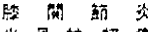 & 435 & 35.8 & 50.7 & 10.6 & 3.1 & 0 & 86.5 \\
\hline 坐骨神柽来 & 354 & 31.7 & 48.5 & 13.0 & 6.5 & 0.3 & 80.2 \\
\hline$\Rightarrow>$ & 102 & 16.7 & 48.7 & 25.6 & 9.0 & 0 & 65.2 \\
\hline 酳 & 83 & 26.0 & 50.6 & 18.5 & 4.9 & 0 & 76.6 \\
\hline 後䫏神柽 & 58 & 32.7 & 49.1 & 14.5 & 3.6 & 0 & 81.8 \\
\hline 助間神柽 & 28 & 40.0 & 44.0 & 8.0 & 8.0 & 0 & 84.0 \\
\hline 三叉神䎦来 & 26 & 18.2 & 45.5 & 36.4 & 0 & 0 & 63.7 \\
\hline 时 箱 & 15 & 30.0 & 50.0 & 10.0 & 10.0 & 0 & 80.0 \\
\hline V & 65 & 30.5 & 47.5 & 18.6 & 3.4 & 0 & 78.0 \\
\hline 船 & 13 & 8.3 & 75.0 & 8.3 & 8.3 & 0 & 83.3 \\
\hline st & 4,374 & 34.6 & 49.4 & 12.7 & 3.4 & 0.1 & 84.0 \\
\hline
\end{tabular}

であり，前回同様に著効，有効のみを有効率とし て算出したが，その結果は $84.0 \%$ であった。

ての方法でみても，著効例は減少したもの〉， 有効例の增加をみて，有効率はこれまでの報告と 殆んど変らなかった。

今回は治療効果を更に別の方法で出してみた。 つまり，乙れまでの方法とは別に，全疾患別に， 全患者の全ての治療後の効果をみて, 何\%が著効, 有効と感じたかを検討してみた。それによると表 に示した如く警くべきことに全治療の50\%で著効 と答え，有効を加えると $88.7 \%$ の治療で有効と感 じていることが解った。このととは勿論，治癒と いらことでなく，あくまでも治療直後の患者のフ ィーリングの問題であるが，いずれにもせよ，て れ来でも述べて来た様に，乙の治療方法が将来の 疼悀の治療の一手段として，有効なものであると 言い得るものと思う。

今後はアンケート調査などを加え，長期の治療 及び治療後の時期的変化などについて検討を加え たいと思う。

治療効果(全症例) その2

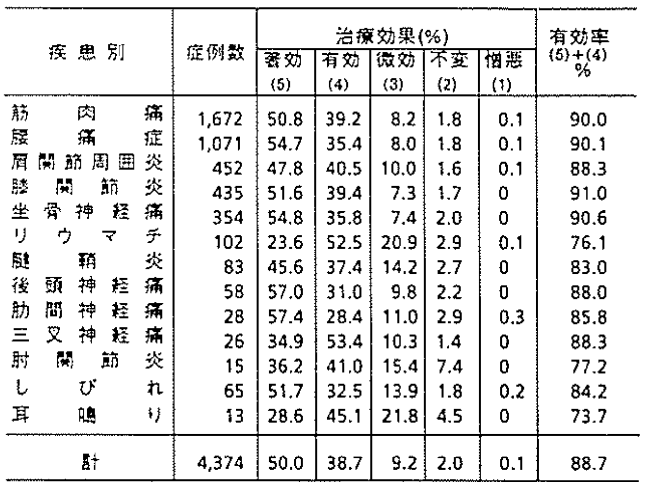

